\title{
STUDI SISTEM BAHAN BAKAR GAS PADA SUPERHEATER UNTUK PENGEMBANGAN BAHAN BAKAR ALTERNATIF
}

\author{
Bambang Puguh Manunggal, M.Eng ${ }^{1}$, Slameto,M.Eng ${ }^{2}$ \\ ${ }^{1}$ Jurusan Teknik Konversi Energi, Politeknik Negeri Bandung \\ ${ }^{2}$ Jurusan Teknik Konversi Energi, Politeknik Negeri Bandung
}

\begin{abstract}
ABSTRAK
Kebutuhan energi di Indonesia terutama penggunaan bahan bakar solar yang semakin meningkat dan emisi gas buang yang semakin tinggi menyebabkan pemanasan global merupakan permasalahan yang perlu diatasi. Untuk itu perlu adanya pengembangan bahan bakar alternatif sebagai pengganti bahan bakar minyak dengan emisi gas buang yang ramah lingkungan. Penggunaan bahan bakar gas sebagai bahan bakar alternatif untuk proses pembakaran di Superheater sangat berpeluang diterapkan di Indonesia dengan cadangan gas yang sangat melimpah. Dalam studi ini, dilakukan pengujian mesin superheater dengan menggunakan bahan bakar Solar. Data awal yang diperlukan antara lain adalah konsumsi bahan bakar, kondisi uap sebelum dan sesudah pembakaran. Analisa pengujian bahan bakar solar meliputi analisa bahan bakar dan aspek ekonomi. Dari hasil analisa tersebut dilakukan perbandingan jika seperheater beroperasi dengan menggunakan bahan bakar gas. Hasil dari pemilihan burner gas dengan Heat Output: $18 \mathrm{sd} 58 \mathrm{KW}, 15.500 \mathrm{sd} 50.000 \mathrm{Kcal} / \mathrm{h}$ dan Tekanan Gas sebesar 16 sd 200 mbar, konsumsi bahan bakar $L P G$ sebesar1,63 kg/jam, jauh lebih rendah dibandingkan konsumsi bahan bakar solar menggunakan oil burner sebesar 3,328 kg/jam Biaya konsumsi bahan bakar LPG menggunakan gas burner sebesar Rp. 21.135/jam, lebih hemat dibandingkan biaya konsumsi bahan bakar solar menggunakan oil burner sebesar Rp. 49.000/jam. Efisiensi termal superheater meningkat dari 38,71\%. menggunakan oil burner menjadi $73,51 \%$, dengan menggunakan gas burner
\end{abstract}

Kata kunci : Bakab bakar alternatif, Superheater, Gas Burner.

\section{PENDAHULUAN}

\section{I.1 Latar Belakang}

Energi merupakan salah satu kebutuhan penting dalam kehidupan manusia. Seiring berjalannya waktu, permintaan akan energi terutama minyak solar/diesel di Indonesia terus meningkat. Peningkatan kebutuhan bahan bakar khususnya minyak solar tentunya akan diikuti dengan peningkatan dampak lingkungan yang ditimbulkan dari pembakaran bahan bakat tersebut. Disamping pengaruh dampak lingkungan, peningkatan permintaan bahan bakar ini akan menguras ketersediaan bahan bakar yang berasal dari minyak bumi. Ketersediaan cadangan minyak bumi yang berasal dari penambangan dalam negeri tidak mampu mengimbangi kebutuhan minyak dalam negeri, sehingga peningkatan kebutuhan ini dipenuhi oleh penambahan dari impor. Melihat ketergantungan yang sangat tinggi dari minyak impor ini, sudah saatnya Indonesia mengkaji pemanfaatan bahan bakar gas untuk memenuhi kebutuhan di sektor industri maupun transportasi, baik LPG, CNG maupun LNG atau gas hasil gasifikasi lainnya sebagai energi bahan bakar yang lebih murah, aman dan ramah lingkungan.

Beberapa penelitian terkait dengan konversi bahan bakat solar ke gas telah banyak dilakukan antara lain oleh Eflita Yohana dan Askhabulyamin (2012) [1],yang melakukan yang penelitian terkait dengan konversi bahan bakar dari minyak solar ke gas pada boiler dan superheater. Pada penelitian ini dibahas tentang perbandingan 
perhitungan biaya yang diperlukan oleh boiler berbahan bakar solar dengan boiler berbahan bakar gas untuk menghasilkan steam output yang sama. Dari perhitungan, kebutuhan bahan bakar yang dikeluarkan untuk boiler dan LNG masing-masing adalah $260,79 \mathrm{~kg} / \mathrm{jam}=0,265 \mathrm{~m} 3 / \mathrm{jam}$ dan 21 $\mathrm{m} 3 /$ jam. Sedangkan untuk biaya yang dikeluarkan $\mathrm{Rp}$ 1.319.797,00/jam dan Rp 27.300,00/jam. Sehingga akan didapat penghematan sebesar Rp 1.292.497,00/jam untuk pembelian bahan bakar. Finus Ainun dan Jamaaluddin (2018) melakukan penelitian perhitungan efisiensi boiler dengan membandingkan bahan bakar minyak solar dengan gas [2]. Dengan menggunakan metode langsung didapatkan hasil rata rata dengan bahan bakar solar adalah $40,7 \%$ dan dengan menggunakan bahan bakar gas berkisar $45,84 \%$.

Pengembangan bahan bakar alternatif dengan gas buang yang ramah lingkungan perlu dilakukan untuk mengatasi permasalahan dampak lingkungan serta kelangkaan energi yang berasal dari minyak bumi tersebut. Dengan melakukan konversi energi dari bahan bakar solar ke bahan bakar gas diharapkan dapat menekan pertumbuhan ketergantungan akan minyak bumi dan digantikan dengan bakan bakar gas.

Dalam penelitian ini akan dilakukan studi pada mesin Superheater di Laboratorium Pembangkit Energi Termal sebagai wujut peran serta pengembangan energi alternatif. Dengan melakukan uji konsumsi bahan bakar pada mesin superheater dapat diprediksi kebutuhan bahan bakar solar pada mesin superheater, selanjutnya akan dapat diprediksi berapa banyak kebutuhan bahan bakar sebagai pengganti solar. Disamping itu dapat dihitung potensi pengaruh dampak lingkungan yang dapat dikendalikan

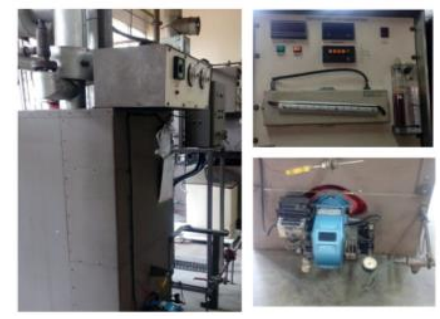

Gambar 1. Unit Superheater dan alat uji emisi gas buang
Jurusan Teknik Konversi Energi memiliki laboratorium Pembangkit Listrik Tenaga Uap (PLTU) dimana salah satunya terdapat Superheater yang melayani beberapa kegiatan praktikum baik dalam rangka mempelajari operasi PLTU hingga melakukan audit kinerja dari PLTU. Selama ini bahan bakar yang digunakan adalah bahan bakar solar. Seiring dengan digaungkannya penggunaan energi alternatif, maka perlu dilakukan studi penggunaan bahan bakar alternatif berupa gas untuk pengoperasinanya.

\section{I.2 Tujuan Penelitian}

Tujuan dari penelitian ini adalah melakukan studi penggunaan bahan bakar alternatif berupa bahan bakar gas sebagai sarana pembakaran pada superheater. Studi dilakukan dengan metode pengujian dengan menggunakan bahan bakar solar. Hasil perhitungan dan analisa penggunaan bahan bakar solar selanjutnya dilakukan analisa jika superheater dioperasikan dengan menggunakan bahan bakar gas. Dengan perbandingan nilai kalor bakan bakar gas serta sifat sifat yang dimiliki bahan bakar gas, dapat dipresiksi konversi bahan bakar gas yang diperlukan serta potensi pengaruh dampak lingkungan yang dapat dikendalikan. Dari hasil penelitian ini diharapkan akan dilakukan penelitian lebih lanjut dengan melakukan retrofit penasangan burner gas yang sesuai.

\section{I.3 Rumusan Masalah}

Superheater merupakan mesin pembakaran yang berada pada deretan pembangkit listrik tenaga uap. Uap dari hasil kerja boiler dialirkan menuju superheater untuk dinaikkan kwalitas uapnya hingga menjadi uap kering dan selanjutnya dialirkan ke turbin uap. Kerja superheater dengan hasil berupa uap dengan kondisi uap panas lanjut dilakukan dengan proses pembakaran menggunakan bahan bakar solar. Dampak dari pembakaran solar ini adalah turut menyumbang emisi lingkungan dari sisa hasil pembakaran. Dengan melakukan analisa perubahan bahan bakar menggunakan bahan bakar gas, dapat diketahui besarnya konsumsi bahan bakar gas dan biaya operasi. 


\section{DASAR TEORI}

\section{II.1 Superheater}

Superheater merupakan mesin pembakaran yang berada pada deretan pembangkit listrik tenaga uap. Uap dari hasil kerja boiler dialirkan menuju superheater untuk dinaikkan kwalitas uapnya hingga menjadi uap kering dan selanjutnya digunakan untuk melakukan kerja pada turbin atau mesin uap. Dengan menggunakan uap kering untuk kerja pada turbin, kemungkinan timbulnya bahaya yang disebabkan terjadinya pukulan balik atau back stroke yang diakibatkan mengembunnya uap belum pada waktunya sehingga menimbulkan vakum di tempat yang tidak semestinya di daerah ekspansi.

Temperatur uap yang dihasilkan superheater sangat dipengaruhi temperatur gas asap. Perbedaan temperatur yang terkecil antara dua aliran gas asap dengan uap disebut dengan titik penyempitan (pinch point) $a-x$ dan $b-y$ (gambar 3) minimum $20^{\circ} \mathrm{C}$. Boiler superheater memproduksi superheated steam atau kering. Uap air ini menyimpan lebih banyak energi panas dari pada uap air saturated (uap air basah), ditandai dengan nilai entalpi yang lebih tinggi. Uap air yang diproduksi oleh boiler konvensional umumnya hanya mencapai fase saturated, dan pada boiler superheater uap air saturated ini akan dipanaskan lebih lanjut mencapai fase superheated. Selain menyimpan energi panas yang lebih besar, uap air superheater juga menghilangkan sifat basah dari uap saturated sehingga tidak akan terjadi kondensasi yang terlalu cepat di dalam mesin yang menggunakan uap air tersebut. Keuntungan utama menggunakan boiler superheater dapat mengurangi konsumsi bahan bakar dan air.

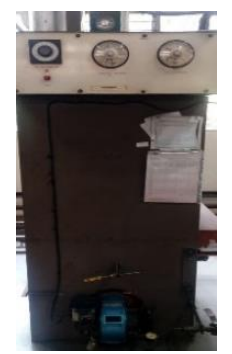

Gambar 2. Superheater

\section{II.2. Minyak Solar}

Bahan bakar solar lebih berat dibandingkan dengan bahan bakar bensin, karena memiliki atom karbon yang banyak dengan rantai karbon yang panjang. Akibatnya, bahan bakar solar lebih stabil dibandingkan bahan bakar bensin. namun memerlukan temperature yang lebih tinggi untuk menguapkanya. Bahan bakar solar sebagian besar terdiri dari senyawa hidrokarbon dan non-hidrokarbon yang mengandung senyawa non-logam.

Bahan bakar solar ini digolongkan berdasarkan jenis putaran mesinnya, yaitu:

\section{- Automotive Diesel Oil}

(ADO), bahan bakar untuk mesin berkecepatan diatas $1000 \mathrm{rpm}$, bahan bakar ini biasanya digunakan untuk kendaraan bermotor.

- Industrial Diesel Oil (IDO), bahan bakar ini digunakan untuk mesin berkecepatan kurang dari atau sama dengan $1000 \mathrm{rpm}$, biasanya digunakan untuk kebutuhan industri.

Untuk menilai kinerja dari bahan bakar solar perlu diketahui mengenai karakteristik minyak solar tersebut. Viskositas tahanan aliran yang dimiliki oleh suatu fluida dalam pipa kapiler terhadap gaya grafitasi. Pada bahan bakar solar yang mempunyai angka cetane yang relatif tinggi maka bahan bakar dapat menyala pada temperature yang rendah.. Bahan bakar solar adalah bahan bakar minyak hasil sulingan dari minyak bumi mentah. Bahan bakar ini berwarna kuning coklat yang jernih (Pertamina: 2005). Sifat sifat utama bahan bakar solar meliputi:

1. Rumus kimia : $\mathrm{C}_{10}-\mathrm{C}_{20}$

2. Warna kekuningan dan berbau

3. Encer dan tidak menguap pada temperatur lingkungan

4. Mempunyai titik nyala yang tinggi $\left(40^{\circ} \mathrm{C}\right.$ $100^{\circ} \mathrm{C}$ )

5. Terbakar secara spontan pada temperatur $350^{\circ} \mathrm{C}$

6. Mempunyai berat jenis sekitar $0.832 \mathrm{~kg} / \mathrm{L}$

7. Mempunyai kandungan sulfur yang lebih besar dari pada bensin

8. Angka Cetana 40-55

9. Nilai kalor bahan bakar (LHV) sebesar $43000 \mathrm{~kJ} / \mathrm{kg}$

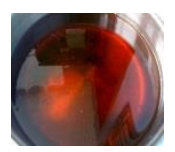

Gambar 3. Minyak solar 
Tabel 1. Spesifikasi Bahan Bakar Minyak Jenis Minyak Solar

\begin{tabular}{|c|c|c|c|c|}
\hline \multirow{2}{*}{ No } & \multirow{2}{*}{ Karakteristik } & \multirow{2}{*}{ Satuan } & \multicolumn{2}{|c|}{ Batasan } \\
\hline & & & Min & $\operatorname{Max}$ \\
\hline \multirow[t]{3}{*}{1} & Bilangan Cetana: & & & \\
\hline & - Angka Cetana & - & 48 & - \\
\hline & - Indeks Cetana & - & 45 & - \\
\hline 2 & Berat Jenis (pada suhu $15^{\circ} \mathrm{C}$ ) & $\mathrm{kg} / \mathrm{m}^{2}$ & 815 & 870 \\
\hline 3 & Viskositas (pada suhu $40^{\circ} \mathrm{C}$ ) & $\mathrm{mm}^{2} / \mathrm{s}$ & 2.0 & 5.0 \\
\hline 4 & Kandungan Sulfur & $\% \mathrm{~m} / \mathrm{m}$ & - & 0.35 \\
\hline \multirow[t]{2}{*}{5} & Distilasi: & & & \\
\hline & T 95 & ${ }^{\circ} \mathrm{C}$ & - & 370 \\
\hline 6 & Titik Nyala & ${ }^{\circ} \mathrm{C}$ & 60 & - \\
\hline 7 & \begin{tabular}{|l|} 
Titik Tuang \\
\end{tabular} & ${ }^{\circ} \mathrm{C}$ & - & 18 \\
\hline 8 & Residu Karbon & $\% \mathrm{~m} / \mathrm{m}$ & - & 0.1 \\
\hline 9 & Kandungan Air & $\mathrm{mg} / \mathrm{kg}$ & - & 500 \\
\hline 10 & Biological growth & - & \multicolumn{2}{|c|}{ Nihil } \\
\hline 11 & Kandungan FAME & $\% \mathrm{v} / \mathrm{v}$ & - & 10 \\
\hline 12 & Kandungan metanol dan etanol & $\% \mathrm{v} / \mathrm{v}$ & \multicolumn{2}{|c|}{ Tak terdeteksi } \\
\hline & & & & Kelas \\
\hline 13 & Korosi Bilah Tembaga & merit & - & 1 \\
\hline 14 & Kandungan Abu & $\% \mathrm{~m} / \mathrm{m}$ & - & 0.01 \\
\hline 15 & Kandungan Sedimen & $\% \mathrm{~m} / \mathrm{m}$ & - & 0.01 \\
\hline 16 & Bilangan Asam Kuat & $\mathrm{mg} \mathrm{KOH} / \mathrm{g}$ & - & 0 \\
\hline 17 & \begin{tabular}{|l|} 
Bilangan Asam Total \\
\end{tabular} & $\mathrm{mg} \mathrm{KOH} / \mathrm{g}$ & - & 0.6 \\
\hline 18 & \begin{tabular}{|l|} 
Partikulat \\
\end{tabular} & $\mathrm{mg} / \mathrm{L}$ & - & - \\
\hline 19 & Penampilan Visual & - & \multicolumn{2}{|c|}{$\begin{array}{l}\text { Jernih dan } \\
\text { terang }\end{array}$} \\
\hline 20 & Wama & No. ASTM & & 3.0 \\
\hline
\end{tabular}

Sumber: Keputusan Direktur Jenderal Minyak dan Gas Bumi, 2006

\section{II.3 CNG}

Gas alam terkompresi (Compressed natural gas, CNG), merupakan bahan bakar alternatif selain bensin atau solar. Komposisi CNG yaitu hanya terdiri dari gas metana $\left(\mathrm{CH}_{4}\right)$ yang di kompresi dan di ekstrak dari gas alam. Biasanya tabung $\mathrm{CNG}$ ini berbentuk silinder. Pengisian CNG dapat dilakukan dari sistem bertekanan rendah maupun tinggi. Untuk penanganan $\mathrm{CNG}$ perlu dilakukan secara berhati-hati. Adapun sifat dari CNG itu sendiri yaitu sebagai berikut:

1. CNG pada dasarnya terdiri dari metana saja.

2. Dari sudut fisik $\mathrm{CNG}$ tidak mencair di bawah tekanan tinggi dan akan tetap dalam bentuk gas, kecuali didinginkan pada saat temperature tertentu.

3. CNG secara langsung berasal dari daerah gas dan proses satusatunya yang dapat dilakukan yaitu hanya menyaring gas, tetapi biasanya gas tersebut dapat langsung digunakan sebagai bahan bakar setelah proses kompresi.

4. CNG ini sebagian besar terdiri dari hidrogen oleh karena itu CNG merupakan bahan bakar yang lebih ringan dari udara. Maka dari itu CNG sangat aman digunakan karena jika terjadi kebocoran dalam sistem maka gas hanya akan dilepas ke atmosfer.

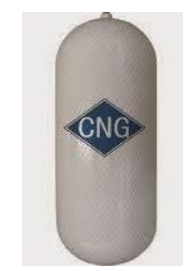

Gambar 4. Tabung gas CNG

Tabel 2. Spesifikasi Kandungan CNG

\begin{tabular}{|l|l|l|}
\hline No. & Karakteristik & $\mathrm{CNG}$ \\
\hline 1 & Komposisi & $\mathrm{CH} 4$ \\
\hline 2 & Densitas & $0,6 \mathrm{~kg} / \mathrm{m}^{3}$ \\
\hline 3 & Berat Molekul & $\begin{array}{l}17,51 \\
\mathrm{~kg} / \mathrm{kmol}\end{array}$ \\
\hline 4 & Nilai Kalori & $\begin{array}{l}47476 \\
\mathrm{kj} / \mathrm{kmol}\end{array}$ \\
\hline 5 & AFR Stoikiometri & 16,15 \\
\hline 6 & $\begin{array}{l}\text { Temperatur } \\
\text { Penyalaan Minimal }\end{array}$ & $521,4^{\circ} \mathrm{C}$ \\
\hline 7 & Kecepatan Nyala & $0,66 \mathrm{~m} / \mathrm{s}$ \\
\hline 8 & Angka Oktan & 130 \\
\hline 9 & LHV & $\begin{array}{l}56328 \\
\mathrm{kj} / \mathrm{kg}\end{array}$ \\
\hline
\end{tabular}

\section{II.4 LPG}

LPG berasal dari hasil pengolahan minyak bumi yang telah melewati proses destilasi bertingkat, dan terjadilah pemisahan berdasarkan nilai titik didih. Minyak mentah mengalami pemisahan menjadi bahan - bahan 
yang lainnya. Dan disinilah terbentuknya LPG (setelah melalui pengolahan lanjutan). Komponen utama dari LPG ini merupakan propane $\left(\mathrm{C}_{3} \mathrm{H}_{8}\right)$ dan butana $\left(\mathrm{C}_{4} \mathrm{H}_{10}\right)$ sebanyak 99\% dengan perbandingan komposisi 30:70 dan $1 \%$ etana $\left(\mathrm{C}_{2} \mathrm{H}_{6}\right)$ juga pentana $\left(\mathrm{C}_{5} \mathrm{H}_{12}\right)$. Reaksi pembakaran gas LPG adalah sebagai berikut :

Propana, $\mathrm{C}_{3} \mathrm{H}_{8}+5 \mathrm{O}_{2} \longrightarrow 3 \mathrm{CO}_{2}+4 \mathrm{H}_{2} \mathrm{O}$ Butana, $2 \mathrm{C}_{4} \mathrm{H}_{10}+13 \mathrm{O}_{2} \longrightarrow 8 \mathrm{CO}_{2}+10 \mathrm{H}_{2} \mathrm{O}$ LPG, $\quad \mathrm{C}_{3} \mathrm{H}_{8}+\mathrm{C}_{4} \mathrm{H}_{10}+11,5 \mathrm{O}_{2} \longrightarrow 7 \mathrm{CO}_{2}+9 \mathrm{H}_{2} \mathrm{O}$ Berikut merupakan sifat dari LPG, yaitu:

1. Wujud

LPG berwujud gas bila dikeluarkan dari tabungnya, namun bila di dalam tabung sebagian berwujud cair dan sebagian berwujud uap. Hal ini diakibatkan oleh adanya perubahan temperature yang diperkecil dan tekanan yang diperbesar.

2. Massa Jenis

Dilihat dari komposisinya, masa jenis butana lebih besar daripada propane dan massa jenis propane lebih besar dari massa jenis udara. Berikut besar massa jenis butana, propane dan udara yaitu sebesar $2,703 \mathrm{~kg} / \mathrm{m}^{3}, 2,004 \mathrm{~kg} / \mathrm{m}^{3}$, dan $1,293 \mathrm{~kg} / \mathrm{m}^{3}$. Karena massa jenis LPG lebih besar dari massa jenis udara maka gas LPG cenderung bergerak kebawah. Massa jenis LPG ketika dalam fase cair yaitu 582,37 $\mathrm{kg} / \mathrm{m}^{3}$ dan dalam fase gas yaitu sebesar 18,357 $\mathrm{kg} / \mathrm{m}^{3}$.

\section{Specific Gravity}

Specific gravity atau yang bisa disebut pula massa jenis relative yaitu perbandingan antara massa jenis gas dengan massa jenis udara. LPG mempunyai nilai massa jenis relatif yang lebih besar dibandingkan dengan udara. Massa jenis dari propana yaitu 1,55 dan butana adalah 0,9. Hal ini menyebabkan dalam penyimpanan diharapkan lebih tinggi sedikit agar bila terjadi kebocoran gas bisa dengan cepat keluar dan bercampur dengan udara.

4. Temperatur Nyala

Temperatur nyala dari propana adalah $510^{\circ} \mathrm{C}$ dan temperatur nyala butana adalah $460^{\circ} \mathrm{C}$. Yang mana bila terjadi kebocoran maka gas tidak kana terbakar dengan sendirinya. Karena untuk menimbulkan nyala pada gas ini dibutuhkan alat penyala.

5. Batas Nyala

Batas nyala merupakan perbandingan campuran antara gas dan udara, dimana pada batas tertentu yang memiliki nilai batas atas dan batas bawah akan terjadi nyala api atau ledakan. Namun bila perbandingan campuran anatara gas dan udara berada di bawah atau di atas batas nyala maka tidak akan terjadi pembakaran. Dan nilai batas nyala (Flammable Range) untuk propan adalah antara 2,4\% sampai dengan 9,6\% dan butan antara 1,9\% sampai dengan 8,6\%.

\section{II.5 Penelitian Terkait}

Beberapa penelitian terkait studi penggunaan bahan bakar gas sebagai pengganti bahan bakar solar antara lain Donal Daniel dan Riza Zulkarnain dari Peneliti dan Pusat Pengkajian dan Perekayasaan Teknologi Kelautan Perikanan pada tahun 2011[3], melakukan pengujian dengan Pemanfaatan Sistem Dual Fuel (Gas LPG-Solar), pengujian dilakukan dengan cara memodifikasi air intake dengan dipasang mixer agar LPG dapat masuk ke ruang bakar. Pengujian dilakukan dengan variasi putaran dan throttle yang dibuka penuh. Hasilnya terjadi penurunan daya karena knocking meskipun terjadi penghematan solar.

Gurski, B \& Guarco, J \& Nunziante, N. pada tahun 2013 melakukan penelitian dengan judul A successful conversion solid fuel to natural gas boiler and firing system [4]. Pada penelitian ini dilakukan dengan memodifikasi bahan bakar menggunakan bahan bakar gas alam, dari penelitian tersebut menunjukan emisi gas buang lebih baik dibandingkan menggunakan bahan bakar padat.

Ahlan Zulfakhri dari Asosiasi Pemuda Maritim Indonesia pada tahun 2013 telah melakukan penelitian mengenai penggunaan bahan bakar gas untuk kapal nelayan [4]. Penelitian ini dilakukan dengan menggunakan DongFeng ZS-1100 dengan putaran yang divariasikan. Dalam penelitian ini didapatkan kesimpulan bahwa penggunaan LPG pada dual fuel mampu menggantikan konsumsi solar seluruhnya sebesar $71 \%$. Komposisi gas LPG yang dihasilkan mencapai $60 \%$ dari total pemakaian bahan bakar saat dual fuel.

Perusahaan Cummins Inc. memproduksi mesin dual fuel QSK50. Mesin ini mampu bekerja dengan $100 \%$ solar atau dual fuel (campuran solar dan bahan bakar gas) [5]. Cara kerja mesin ketika 
menggunakan bahan bakar ganda yaitu, gas masuk bersama dengan udara ditarik ke dalam silinder dengan perbandingan udara-bahan bakar yang lebih kecil dibanding saat single fuel. Bahan bakar diesel masuk saat akhir tekanan kompresi, dan terjadilah pembakaran. Gas menggantikan diesel dengan tingkat penggantian $50-70 \%$. Tingkat penggantian maksimum yaitu $70 \%$ yang dapat dicapai oleh Cummins Dual Fuel untuk aplikasi dengan faktor beban tinggi. Pada rentang nilai tingkat substitusi ini lah, mesin dapat bekerja dengan baik, dan merupakan pergantian bahan bakar diesel menjadi bahan bakar gas maksimal.

\section{HASIL PENELITIAN}

III.1 Pengujian Oil Burner pada Superheater Pengujian oil burner dilakukan berdasarkan waktu yaitu per satu menit menggunakan stopwatch. Pengujian dilakukan hingga temperatur keluar superheater ( $\mathrm{P}_{\text {out }}$ sup $)$ mencapai $240^{\circ} \mathrm{C}$ dan tekanan boiler $\left(\mathrm{P}_{\text {boiler }}\right)$ sebesar 4 bar dengan kualitas uap (x) adalah 0,9 . Kualitas uap diukur menggunakan kalorimeter yang bekerja dengan cara memisahkan uap dan air pada uap basah. Uap mengalir melalui condenser untuk dicairkan. Berdasarkan pengukuran selama 7 menit untuk mendapatkan kondensat hasil pendinginan uap $\left(\mathrm{V}_{\text {kondensat }}\right)$ sebanyak 1.000 $\mathrm{mL}$, didapat air yang terpisahkan dari uap $\left(\mathrm{V}_{\text {air }}\right)$ sebanyak $100 \mathrm{~mL}$.

$\mathrm{X}=\frac{\mathrm{V}_{\text {kondensat }}}{\mathrm{V}_{\text {air }}+\mathrm{V}_{\text {kondensat }}}=\frac{1.000 \mathrm{~mL}}{(100+1.000) \mathrm{mL}}=0,9$

Data hasil pengujian oil burner disajikan pada Tabel 3

Tabel 3. Data hasil pengujian oil burner pada superheater

\begin{tabular}{|c|c|c|c|c|c|c|c|}
\hline $\begin{array}{c}\mathrm{t} \\
\text { (menit) }\end{array}$ & $\begin{array}{l}\mathrm{V}_{\mathrm{bb}} \\
\text { (L) }\end{array}$ & $\begin{array}{l}T_{\text {steam in }} \\
\left({ }^{\circ} \mathrm{C}\right)\end{array}$ & $\begin{array}{c}T_{\text {stteam out }} \\
\left({ }^{\circ} \mathrm{C}\right)\end{array}$ & $\begin{array}{l}\mathrm{T}_{\mathrm{gb}} \\
\left({ }^{\circ} \mathrm{C}\right)\end{array}$ & $\begin{array}{l}\text { Pout sup } \\
\text { (bar) }\end{array}$ & $\begin{array}{c}P_{\text {uap }} \\
(\mathrm{mmHg})\end{array}$ & $\begin{array}{r}\dot{\mathrm{m}} \\
(\mathrm{kg}\end{array}$ \\
\hline 0,5 & 0 & 149 & 156 & 272 & \multirow{6}{*}{5} & 150 & $\overline{1}$ \\
\hline 1 & 0 & 149 & 173 & 323 & & 150 & $\overline{1}$ \\
\hline 1,5 & 0,1 & 148 & 201 & 367 & & 142 & $\overline{1}$ \\
\hline 2 & 0,1 & 147 & 220 & 389 & & 130 & 1 \\
\hline 2,5 & 0,1 & 147 & 233 & 392 & & 132 & 1 \\
\hline 3 & 0,2 & 146 & 240 & 386 & & 132 & $\overline{1}$ \\
\hline
\end{tabular}

Volume diukur menggunakan alat ukur fuel flow pada instrumen superheater yang ditunjukkan oleh Gambar III.2.

Diketahui:

- $\rho_{\text {solar }}$ $=0,832 \mathrm{~kg} / \mathrm{L}$
- $\mathrm{N}_{\mathrm{kbb} \text { solar }}=44.998,92 \mathrm{~kJ} / \mathrm{kg}$

Berdasarkan data pada pengambilan data saat 3 menit, maka konsumsi bahan bakar ( $\left.\dot{\mathrm{m}}_{\mathrm{bb}}\right)$, efisiensi termal superheater ( $\eta$ ), dan biaya bahan bakar untuk pengujian oil burner yaitu sebagai berikut:

1. Konsumsi Bahan Bakar (mbb)

$$
\begin{aligned}
& \text { a. } \mathrm{Q}_{\mathrm{bb} \text { solar }}=\frac{\mathrm{V}_{\mathrm{bb}}}{\mathrm{t}} \\
& =\frac{0,2 \mathrm{~L}}{3 \mathrm{menit}} \times \frac{60 \mathrm{menit}}{1 \mathrm{jam}} \\
& =4 \mathrm{~L} / \mathrm{jam}
\end{aligned}
$$

2. Efisiensi Termal Superheater ( $\mathrm{n}$ )

a. Entalpi Uap (h)

Berdasarkan tabel A-4

Properties of Saturated Water yang terdapat pada Lampiran B, didapatkan:

$\begin{array}{ll}\mathrm{T}_{\text {steam in }} & =146{ }^{\circ} \mathrm{C}, \\ \mathrm{h}_{\mathrm{f}} & =614,97 \mathrm{~kJ} / \mathrm{kg} \\ \mathrm{h}_{\mathrm{fg}} & =2.126,46 \mathrm{~kJ} / \mathrm{kg}\end{array}$

Berdasarkan tabel A-6

Properties of Superheated Water

Vapor yang terdapat pada

Lampiran B, didapatkan:

$\mathrm{T}_{\text {steam out }}=240{ }^{\circ} \mathrm{C}$,

$\mathrm{h}_{\text {sup }} \quad=2.939,9 \mathrm{~kJ} / \mathrm{kg}$

b. Energi yang diterima uap $\left(\mathrm{E}_{\text {steam }}\right)$

$$
\begin{aligned}
& \mathrm{E}_{\text {steam }}=\dot{\mathrm{m}}_{\mathrm{u}}\left(\mathrm{h}_{\text {sup }}-\left(\mathrm{h}_{\mathrm{f}}+\right.\right. \\
& \left.\left.\mathrm{x} \cdot \mathrm{h}_{\mathrm{fg}}\right)\right)=141 \frac{\mathrm{kg}}{\mathrm{jam}} \times(2.939,9- \\
& (614,97+(0,9 \times 2.126,46))) \\
& \mathrm{kJ} / \mathrm{kg}=57.967,36 \mathrm{~kJ} / \mathrm{jam}
\end{aligned}
$$

c. Energi hasil pembakaran $\left(\mathrm{E}_{\mathrm{bb}}\right)$

$$
\begin{aligned}
\mathrm{E}_{\mathrm{bb}} & =\dot{\mathrm{m}}_{\mathrm{bb}} \times \mathrm{N}_{\mathrm{kbb} \text { solar }} \\
=3,328 & \frac{\mathrm{kg}}{\mathrm{jam}} \times 44998,92 \frac{\mathrm{kJ}}{\mathrm{kg}} \\
& =149.756,41 \mathrm{~kJ} / \mathrm{jam}
\end{aligned}
$$

d. Efisiensi Termal ( $n)$

$$
\begin{aligned}
\eta & =\frac{E_{\text {steam }}}{E_{\text {bb }}} \times 100 \% \\
& =\frac{57.967,36 \mathrm{~kJ} / \mathrm{jam}}{149.756,41 \mathrm{~kJ} / \mathrm{jam}} \times 100 \% \\
& =38,71 \%
\end{aligned}
$$

3. Biaya Konsumsi Bahan Bakar Harga Solar = Rp. 12.250/L 
Total Biaya $=$ Harga solar $\times Q_{b b}$ solar $=\frac{R p .12 .250}{L} \times 4 \mathrm{~L} / \mathrm{jam}$

$=$ Rp. $49.000 /$ jam

\section{III.2 Pemilihan Burner Gas}

Pemilihan burner gas didasarkan pada data pengujian superheater dengan menggunakan burner berbahan bakar solar. Hasil uji dengan menggunakan bahan bakar solar menunjukan nilai konsumsi solar per waktu adalah 0,3 liter/3 menit. Dengan memperhitungkan massa jenis solar $\left(\rho_{\text {solar }) \text { sebesar }} 0,832(\mathrm{~kg} / \mathrm{L})\right.$ dan nilai kalor bahan bakar solar ( $\mathrm{N}_{\mathrm{kbb} \text { solar }}$ ) sebesar $44.998,92 \mathrm{~kJ} / \mathrm{kg}$, maka konsumsi bahan bakar solar adalag sebesar $149.756,41 \mathrm{~kJ} / \mathrm{jam}$, atau setara dengan 41,043 (KW).

\subsubsection{Pertimbangan konsumsi kalor} bahan bakar

Dengan perilaku konsumsi bahan bakar solar yang cenderung konstan sebesar 149.756,41 $\mathrm{kJ} / \mathrm{jam}$, atau setara dengan 41,043 (KW). maka dapat dilakukan pendekatan pemilihan burner gas yang sesuai dengan konsumsi energi untuk operasi pembakaran pada superheater. Beberapa spesifikasi yang telah dipilih antara lain:

Tabel 6. Spesifikasi Gas burner

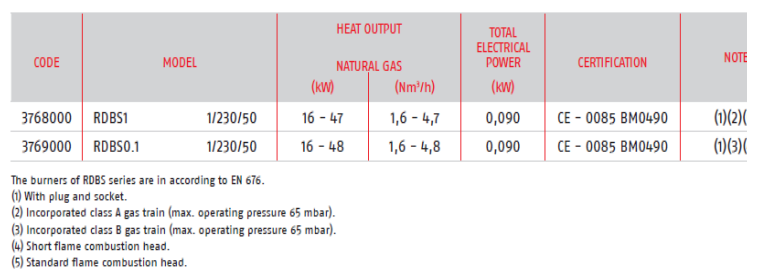

Sumber: www.rielloburners.co.uk

Dilihat dari kebutuhan energi bahan bakar sebesar 41,043 KW, maka pendekatan yang sesuai adalah dengan menggunakan burner gas dengan heat output dengan menggunakan Natural gas berkisar antara $16 \mathrm{KW}$ sampai 48 KW.

III.2.1 Pertimbangan dimensi dan bentuk burner

Pemilihan dimensi merupakan pertimbangan kesesuaian bentuk dan ukuran apakan burner gas yang dipilih dapat dipasang pada superheater. Dengan dimensi lubang burner pada superheater sebesar $95 \mathrm{~mm}$, maka dipilih tipe burner dengan ukuran combustion head sebesar $91 \mathrm{~mm}$, seperti terlihat pada gambar dibawah.

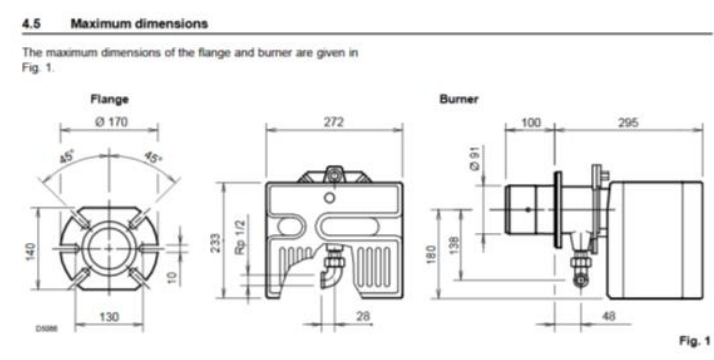

Gambar 9. Dimensi burner gas

\section{III.2.2 Spesifikasi Burner Gas}

Berdasarkan hasil pengujian superheater dengan menggunakan bahan bakar cair dengan konsumsi bahan bakar sebesar 44.998,92 kJ/kg, maka konsumsi bahan bakar solar adalag sebesar $149.756,41 \mathrm{~kJ} / \mathrm{jam}$, atau setara dengan 41,043 (KW). Maka direkomendasikan pemilihan burner gas yang sesuai dengan kebutuhan pembakaran pada superheater.

\section{Tabel 7. Data Teknik Gas burner}

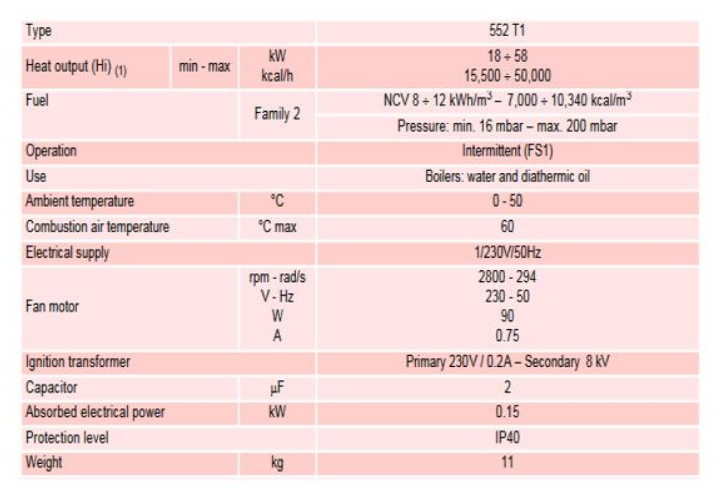

Data Teknis Konsumsi bahan bakar gas sebesar :1,63 kg/jam atau setara dengan 3,13 L/jam akan merubah uap dari temperature 146 ${ }^{\circ} \mathrm{C}$ dengan Entalpi Uap $2.126,46 \mathrm{~kJ} / \mathrm{kg}$ menjadi uap pada temperature $240{ }^{\circ} \mathrm{C}$ dengan Entalpi sebesar 2.939,9 kJ/kg akan menghasilkan efisiensi pembakaran sebesar 73,51 \%. Denganharga gas LPG sebesar Rp. $13.000 / \mathrm{kg}$ atau setara dengan Rp. 6.760/L, maka biaya operasi superheater adalah sebesar Rp. 21.135/jam

III.2.3 Perbandingan Hasil Pengujian Oil Burner dan Gas Burner Burner Gas

Berdasarkan hasil pengolahan data, perbandingan hasil pengujian bahan bakar solar menggunakan oil burner dan asumsi menggunakan perbandingan data teknis 
konsumsi bahan bakar dengan Burner Gas maka dapat dilakukan beberapa analisa antara lain :

1. Konsumsi Bahan Bakar Solar dan $L P G$

Perbandingan konsumsi bahan bakar solar menggunakan oil burner dan bahan bakar $L P G$ menggunakan data teknis gas burner disajikan pada Gambar IV.1.

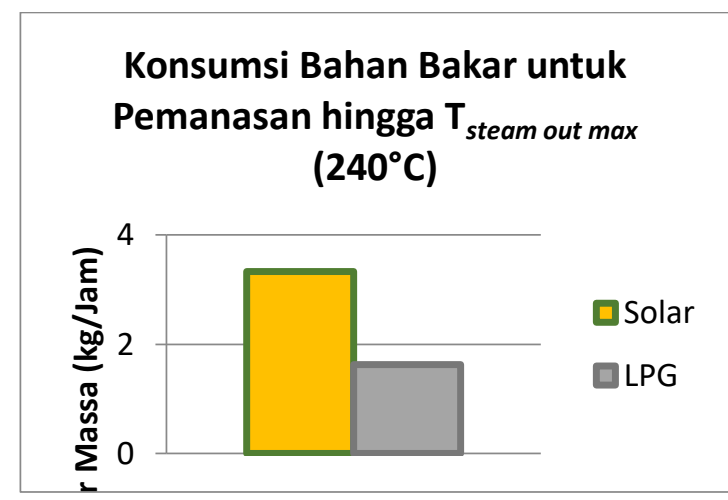

Gambar 10. Grafik perbandingan konsumsi bahan bakar solar dan $L P G$

Gambar 10. merupakan perbandingan konsumsi bahan bakar solar dan LPG. Konsumsi bahan bakar solar yaitu sebesar 3,328 kg/jam sedangkan konsumsi bahan bakar $L P G$ yaitu $1,63 \mathrm{~kg} / \mathrm{jam}$ untuk memanaskan uap hingga temperatur uap keluar superheater ( $\left.\mathrm{T}_{\text {steam out }}\right)$ sebesar $240^{\circ} \mathrm{C}$. Konsumsi bahan bakar $\left(\dot{\mathrm{m}}_{\mathrm{bb}}\right) \quad L P G$ lebih sedikit dibandingkan solar dikarenakan gas burner berbahan bakar $L P G$ dapat memanaskan uap sebesar $94^{\circ} \mathrm{C}$ dalam waktu 155 detik atau 2,58 menit dengan konsumsi bahan bakar $L P G$ sebanyak 1,63 kg/jam sedangkan oil burner berbahan bakar solar dapat memanaskan uap sebesar $94^{\circ} \mathrm{C}$ dalam waktu 3 menit dengan konsumsi bahan bakar solar sebanyak 3,328 $\mathrm{kg} / \mathrm{jam}$. Hal tersebut dikarenakan jumlah konsumsi bahan bakar berpengaruh terhadap energi hasil pembakaran bahan bakar[4], sehingga nilai energi hasil pembakaran bahan bakar $L P G$ lebih rendah dibandingkan energi hasil pembakaran bahan bakar solar. Nilai energi hasil pembakaran $L P G$ yaitu sebesar 79.414,14 kJ/jam dengan konsumsi bahan bakar sebanyak 1,63 kg/jam sedangkan nilai energi hasil pembakaran solar yaitu sebesar 149.756,41 kJ/jam dengan konsumsi bahan bakar sebanyak 3,328 kg/jam. Konsumsi bahan bakar dipengaruhi nilai kalor bahan bakarnya, satu kilogram $L P G$ dapat menghasilkan energi sebesar 48.846 $\mathrm{kJ}$ sedangkan satu kilogram solar dapat menghasilkan energi sebesar 44.998,92 kJ.

2. Biaya Konsumsi Bahan Bakar Solar dan $L P G$

Perbandingan biaya konsumsi bahan bakar solar menggunakan oil burner dan bahan bakar $L P G$ menggunakan gas burner disajikan pada Gambar IV.4. Biaya gas burner berbahan bakar $L P G$ dibandingkan dengan biaya oil burner berbahan solar dengan harga solar yang diperuntukkan untuk industri.

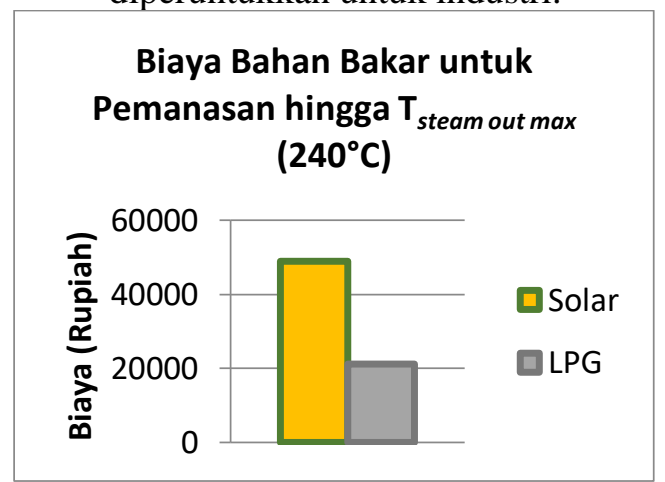

Gambar 11. Grafik perbandingan biaya konsumsi solar dan $L P G$

Gambar 11 merupakan perbandingan antara biaya yang perlu dikeluarkan untuk konsumsi bahan bakar solar menggunakan oil burner dan konsumsi bahan bakar $L P G$ menggunakan gas burner. Biaya bahan bakar solar sebesar Rp. 49.000/jam, lebih mahal dibandingkan dengan biaya konsumsi bahan bakar $L P G$ yaitu senilai Rp. 21.135/jam untuk memanaskan uap hingga temperatur uap $\left(\mathrm{T}_{\text {steam out }}\right)$ sebesar $240^{\circ} \mathrm{C}$. Biaya konsumsi bahan bakar solar lebih mahal dibandingkan biaya $L P G$ dikarenakan konsumsi solar yang lebih banyak daripada konsumsi $L P G$ serta harga solar lebih mahal per liternya walaupun debitnya lebih rendah. 
Efisiensi termal superheater untuk pengujian oil burner yaitu sebesar 38,71\% sedangkan efisiensi termal superheater untuk pengujian gas burner lebih besar yaitu sebesar $73,51 \%$. Nilai efisiensi termal superheater menggunakan gas burner berbahan bakar $L P G$ lebih besar dikarenakan energi hasil pembakaran $L P G$ lebih banyak yang diserap uap untuk menaikkan temperatur hingga $240^{\circ} \mathrm{C}$ daripada energi hasil pembakaran solar[5]. Energi yang diserap uap pada pengujian gas burner yaitu $58.378,47 \mathrm{~kJ} / \mathrm{jam}$ dan energi yang diserap uap pada pengujian oil burner yaitu 57.967,36 kJ/jam dengan sumber energi yang diserap berasal dari energi hasil pembakaran bahan bakar yang berbeda.

\section{KESIMPULAN}

Berdasarkan analisa, perhitungan dan referensi pada bab VI, maka burner terpasang pada superheater $P 7623$ menggunakan oil burner Nu-way NLO2, tipe Single Coil, independently oil fired, dengan tekanan kerja 5 sd 10,3 bar, dapat digantikan dengan menggunakan burner berbahan bakar gas dengan spesifikasi :

1. Spesifikasi Burner

$$
\begin{array}{ll}
\circ & \text { Type : Gas Burner } \\
\circ & \text { Heat Output : } 18 \mathrm{sd} 58 \\
& \mathrm{KW}, 15.500 \mathrm{sd} 50.000 \mathrm{Kcal} / \mathrm{h} \\
& \text { Tekanan Gas : } 16 \mathrm{sd} 200 \\
\text { mbar }
\end{array}
$$

2. Konsumsi bahan bakar

Konsumsi bahan bakar ( $\left.\dot{\mathrm{m}}_{\mathrm{bb} \text { LPG }}\right) L P G$ menggunakan gas burner yaitu $1,63 \mathrm{~kg} / \mathrm{jam}$, lebih rendah dibandingkan konsumsi bahan bakar ( $\dot{\mathrm{m}}_{\mathrm{bb} \text { solar }}$ ) solar menggunakan oil burner yaitu $3,328 \mathrm{~kg} / \mathrm{jam}$ untuk memanaskan uap keluar superheater $\left(\mathrm{T}_{\text {steam out }}\right)$ hingga $240^{\circ} \mathrm{C}$.

3. Estimasi biaya operasi

Biaya konsumsi bahan bakar $L P G$ menggunakan gas burner yaitu Rp. 21.135/jam, lebih hemat dibandingkan biaya konsumsi bahan bakar solar menggunakan oil burner yaitu Rp. 49.000/jam untuk memanaskan uap keluar superheater $\left(\mathrm{T}_{\text {steam }}\right.$ out) hingga $240^{\circ} \mathrm{C}$.

4. Estimasi efisiensi

Efisiensi termal superheater menggunakan gas burner yaitu $73,51 \%$, lebih rendah dibandingkan efisiensi termal superheater menggunakan oil burner yaitu $38,71 \%$.

\section{DAFTAR PUSTAKA}

1. Donal Daniel dan Riza Zulkarnain, 2013, Pemanfaatan Sistem Dual Fuel ( Gas LPG dan Solar), Pusat Pengkajian dan Perekayasaan Teknologi Kelautan Perikanan.

2. Eflita Yohana dan Askhabulyamin, 2012, Perhitungan Efisiensi Dan Konversi Dari Bahan Bakar Solar Ke Gas Pada Boiler Ebara HKL 100 KA, Universitas Diponegoro Semarang.

3. Finus Ainun dan Jamaaluddin (2018) Perhitungan Perbandingan Efisiensi Boiler Dengan Membandingkan Bahan Bakar Minyak Solar Dengan Gas.

4. Gurski, Bill \& Guarco, John \& Nunziante, Nando. (2014). Solid Fuel to Natural Gas Conversions for Circulating Fluid Bed Boilers.

5. https://www.prosesindustri.com/2015/02/ defenisi-bahan-bakar-diesel-solar.html

6. http://www.litbang.esdm.go.id/buku$\mathrm{km} /$ penelitian-aplikasi-dan-kinerja-dmemurni-sebagai-bahan-bakar-alternatifsubstitusi-lpg-untuk-burner-industri-kecil

7. https://maul24hours.wordpress.com/201 1/10/29/karakteristik-natural-gas-ngdan-compressed-natural-gas-cngsebagai-bahan-bakar-alternatifl

8. https://id.scribd.com/doc/297573898/Kar akteristik- $L P G$ 